\title{
Chemical constituents of essential oil from Murraya paniculata leaves and its application to in vitro biological control of the fungus Sclerotinia sclerotiorum
}

Flávia Fernanda Alves da SILVA ${ }^{1}$, Cassia Cristina Fernandes ALVES ${ }^{1}$ (D), Josemar Gonçalves de OLIVEIRA FILHO ${ }^{1}$, Tatiana Manzini VIEIRA², Antônio Eduardo Miller CROTTI² (D), Mayker Lazaro Dantas MIRANDA ${ }^{3 *}$

\begin{abstract}
Besides their value as therapeutic resources, medicinal plants may also be used as sources of active ingredients against phytopathogens. Fungi can grow and cause spoilage in food, thus, resusting in decrease in its quality and quantity. This research aimed at evaluating the effect of essential oil from Murraya paniculata (ML-EO) leaves on mycelial growth of Sclerotinia sclerotiorum, a fungus that poses high risk to several cultures, mainly soybean. Essential oil from M. paniculata (Rutaceae) leaves was obtained by hydrodistillation which was carried out by a Clevenger-type apparatus while its chemical composition was analyzed by GC-FID and GC-MS. $\beta$-Caryophyllene (23.8\%), $\alpha$-zingiberene (21.0\%) and $\beta$-cubebene (10.2\%) were the main constituents found in ML-EO leaves. In vitro antifungal activity showed that ML-EO, at a $300 \mu \mathrm{L}$ dose, inhibited $91.2 \%$ of mycelial growth of Sclerotinia sclerotiorum. This is the first report of the antifungal activity of ML-EO against S. sclerotiorum and results suggest that the essential oil under evaluation has good potential to control this phytopathogenic fungus.
\end{abstract}

Keywords: phytopathogen; Rutaceae; soybean; alternative control; plant disease.

Practical Application: Possible application of a natural product as an antifungal in agriculture.

\section{Introduction}

Soybean cultivation has been one of the most economically important productive activities economically in Brazil and in the world. It may result from several factos, such as the development of more productive cultivars, and has made Brazil become the second largest producer and exporter of this culture worldwide. However, some factors, such as plant diseases, mainly white mold, have negatively contributed to soybean productivity (Pereira et al., 2012).

Sclerotinia sclerotiorum is a phytopathogenic fungus that causes a disease known as white mold, which is one of the main factors that prevents cultures, such as soybean (Glycine max (L.) Merrill) ones, from reaching high productivity (Dildey et al., 2014). White mold is disseminated by infected seeds due to the fact that the pathogen survives in the soil for a long time by means of structures named sclerotia in favorable environmental conditions, such as temperature, soil moisture and depth at which they are found in the soil. As a result, the population of the disease increases every time cultures of the same host species are planted (Silva et al., 2018).

The high rate of diseases caused by phytopathogens makes Brazil consume about $50 \%$ of the quantity of agrochemicals used in Latin America. The country is considered one of the largest consumers of agrochemicals worldwide, since it spends about U\$ 2.5 million yearly to buy these products. Their use leads to harmful consequences, such as environmental imbalance and, mainly, contamination of food, animals and water reserves, thus, decreasing the population's expectation and quality of life (Fonseca et al., 2015).

Researches on alternate control of plagues and diseases, mainly the ones that trigger economic losses to agriculture, with the use of essential oils extracted from plants have been carried out lately to reveal their promising potential to control phytopathogens, such as the fungus Sclerotinia sclerotiorum (Alam et al., 2017; Silva et al., 2018).

Murraya paniculata, which belongs to the family Rutaceae, is a tree native to India that was brought to Brazil, where it has been widely used for urban afforestation in São Paulo, SP. This species is considered medicinal in tropical and subtropical Asian regions, China and Indonesia. In these countries, leaves and roots have been used for treating intestinal disorders, rheumatism and cough (Mesquita et al., 2008). Besides, this is the first evaluation of in vitro activity of essential oil from M. paniculata leaves against Sclerotinia sclerotiorum.

Studies carried out by this research group have aimed at analysing the chemical composition and biological activities of essential oils (Estevam et al., 2017; Estevam et al., 2018), and this one, specifically, addresses the chemical composition and the in vitro antifungal activity of $M$. paniculata (Figure 1) against $S$. sclerotiorum. 

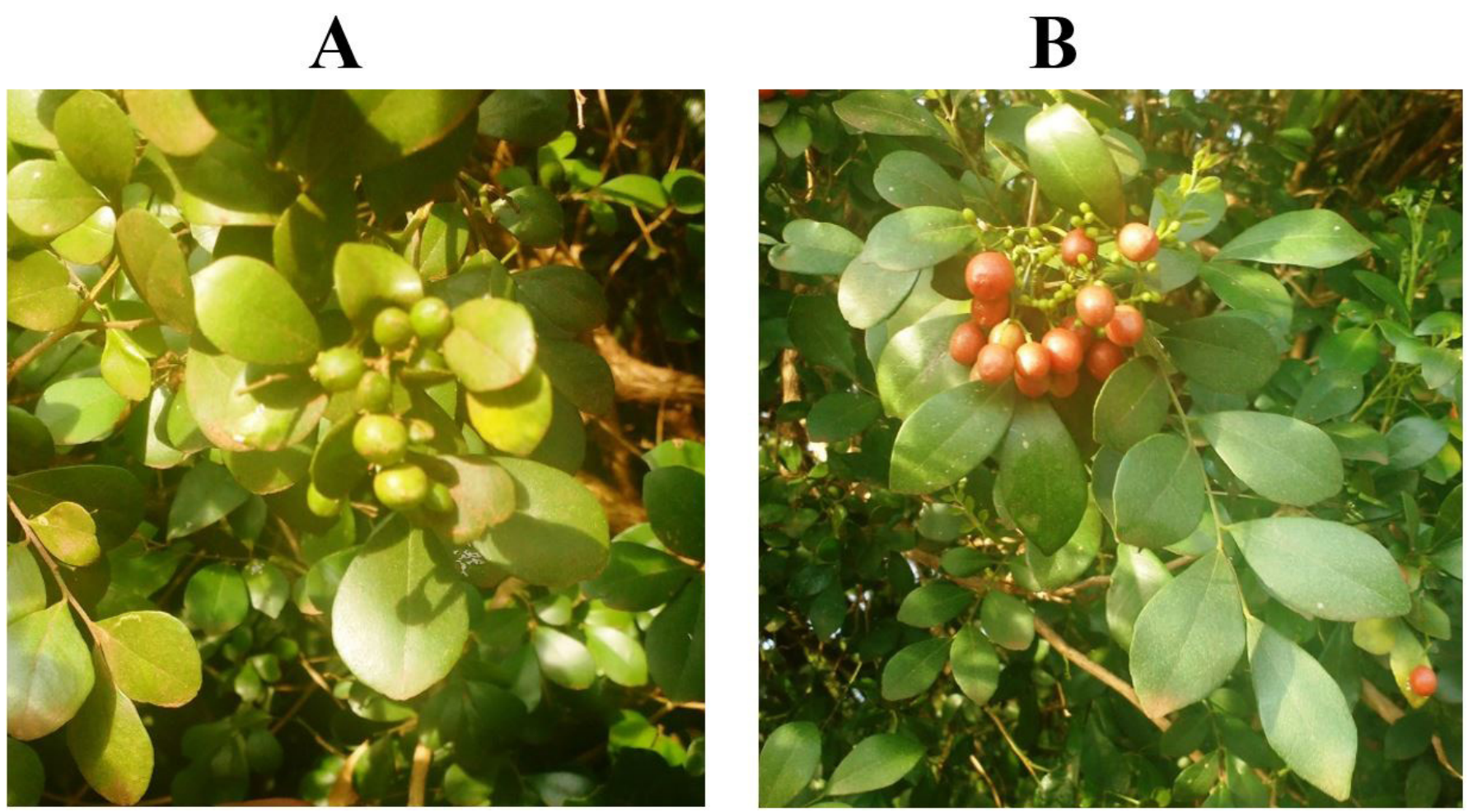

Figure 1. Murraya paniculata leaves and unripe fruits (A); Murraya paniculata leaves and ripe fruits (B).

\section{Materials and method}

\subsection{Plant material}

Murraya paniculata leaves were collected on June 10th, 2017, at 8 am, in Rio Verde, Goiás, Brazil, on the campus of the Instituto Federal Goiano - Rio Verde. The plant was identified by the botanist Erika Amaral and a sample was deposited at the Herbarium Jataiense Professor Germano Guarim Neto at exsiccate number HJ 28760/MP.

\subsection{Extraction of essential oil}

Samples of $M$. paniculata leaves were subjected to hydrodistillation for 2 hours by a Clevenger-type apparatus. In order to carry out the analysis, $300 \mathrm{~g}$ plant material was divided into three 100-g samples and $500 \mathrm{~mL}$ distilled water was added to each sample. After manual collection of the essential oil samples, traces of remaining water in the oils were removed with anhydrous sodium sulfate and then filtered. The extraction procedure was done in triplicate. Isolated oils were stored under refrigeration up to the analysis and test. Yields (w/w) were calculated from fresh leaf and inflorescence weight and expressed as the average of triplicate analyses.

\subsection{Identification of the chemical composition of essential oil}

Gas chromatography (GC) analyses were performed by a Shimadzu GC2010 Plus gas chromatograph equipped with an AOC-20s autosampler and fitted with FID and a data-handling processor. An Rtx-5 (Restek Co., Bellefonte, PA, USA) fused silica capillary column (30-m x 0.25-mm i.d.; 0.25- $\mu \mathrm{m}$ film thickness) was employed. Operation conditions were as follows: the column temperature was programmed to rise from 60 to $240{ }^{\circ} \mathrm{C}$ at $3{ }^{\circ} \mathrm{C} / \mathrm{min}$ and, then, to hold at $240{ }^{\circ} \mathrm{C}$ for $5 \mathrm{~min}$; carrier gas $=\mathrm{He}$ (99.999\%), at $1.0 \mathrm{~mL} / \mathrm{min}$; injection mode; injection volume, $0.1 \mu \mathrm{L}$ (split ratio of 1:10); and injector and detector temperatures were 240 and $280{ }^{\circ} \mathrm{C}$, respectively. Relative concentrations of components were obtained by peak area normalization (\%). Relative areas were the average of triplicate GC-FID analyses.

GC-MS analyses were carried out by a Shimadzu QP2010 Plus (Shimadzu Corporation, Kyoto, Japan) system equipped with an AOC-20i autosampler. The column was an RTX-5MS (Restek Co., Bellefonte, PA, USA) fused silica capillary column (30 $\mathrm{m}$ x $0.25 \mathrm{~mm}$ i.d. $\times 0.25 \mu \mathrm{m}$ film thickness). Electron ionization mode occurred at $70 \mathrm{eV}$. Helium (99.999\%) was employed as the carrier gas at constant flow of $1.0 \mathrm{~mL} / \mathrm{min}$. Injection volume was $0.1 \mu \mathrm{L}$ (split ratio of 1:10). Injector and ion-source temperatures were set at 240 and $280{ }^{\circ} \mathrm{C}$, respectively. The oven temperature program was the same as the one used for GC. Mass spectra were taken at scan intervals of $0.5 \mathrm{~s}$, in the mass range from 40 to $600 \mathrm{Da}$.

Identification of volatile components of M. paniculata leaves (Table 1) was based on their retention indices on an Rtx-5MS capillary column under the same operating conditions as the ones in the case of GC relative to a homologous series of $n$-alkanes $\left(\mathrm{C}_{8}-\mathrm{C}_{20}\right)$. Structures were computer-matched with the Wiley 7 , NIST 08 and FFNSC 1.2 spectra libraries and their fragmentation patterns were compared with literature data (Adams, 2007). 
Table 1. Chemical composition of essential oil from M. paniculata leaves collected in Rio Verde, Goiás, Brazil.

\begin{tabular}{|c|c|c|c|c|}
\hline Compounds & $\mathrm{RI}_{\text {exp }}$ & $\mathrm{RI}_{\text {lit }}$ & RA \% & Identification \\
\hline$\alpha$-Ylangene & 1365 & 1372 & 5.6 & RL MS \\
\hline a-Copaene & 1375 & 1376 & 1.6 & RL MS \\
\hline$\beta$-Bourbonene & 1377 & 1384 & 0.6 & RL MS \\
\hline$\beta$-Cubebene & 1385 & 1390 & 10.2 & RL MS \\
\hline$\beta$-Caryophyllene & 1415 & 1418 & 23.8 & RL MS \\
\hline$\beta$-Humulene & 1446 & 1440 & 6.4 & RL MS \\
\hline Aromadendrene & 1461 & 1464 & 1.8 & RL MS \\
\hline Germacrene D & 1476 & 1480 & 9.8 & RL MS \\
\hline a-Zingiberene & 1492 & 1495 & 21.0 & RL MS \\
\hline$\beta$-Bisabolene & 1501 & 1509 & 1.2 & RL MS \\
\hline trans-Nerolidol & 1557 & 1565 & 1.4 & RL MS \\
\hline Spathulenol & 1576 & 1576 & 2.5 & RL MS \\
\hline Caryophyllene oxide & 1581 & 1581 & 1.5 & RL MS \\
\hline t-Cadinol & 1634 & 1640 & 0.4 & RL MS \\
\hline 10-epi- $\alpha$-Muurolol & 1640 & 1641 & 2.6 & RL MS \\
\hline a-Cadinol & 1654 & 1653 & 1.0 & RL MS \\
\hline \multicolumn{3}{|c|}{ Sesquiterpene hydrocarbons } & \multicolumn{2}{|r|}{88.3} \\
\hline \multicolumn{3}{|c|}{ Oxygenated sesquiterpenes } & \multicolumn{2}{|r|}{9.4} \\
\hline \multicolumn{3}{|c|}{ Total } & \multicolumn{2}{|r|}{97.7} \\
\hline
\end{tabular}

$\boldsymbol{R T}$ : Retention time; $\boldsymbol{R \boldsymbol { I } _ { \text { exp } }}$ : Retention index determined in relation to $n$-alkanes $\left(\mathrm{C}_{8}-\mathrm{C}_{20}\right)$ in the Rtx-5MS column; $\boldsymbol{R I}_{\text {lit }}$ : Retention index fromthe literature (Adams, 2007); $\boldsymbol{R A} \%$ : relative area (peak area in relation to the total peak area in the GC-FID chromatogram), average of three replicates; $\boldsymbol{R} \boldsymbol{L}$ : comparison between $\boldsymbol{R} \boldsymbol{I}_{\text {exp }}$ and the literature (Adams, 2007); MS: comparison between mass spectra and Wiley 7. NIST 08. and FFNSC 12 libraries as well as those found in the literature (Adams, 2007).

\subsection{In vitro antifungal activity of essential oil from M. paniculata leaves against the phytopathogen S. sclerotiorum}

The isolate of Sclerotinia sclerotiorum Ss12 (BRM 29673) was provided by the Embrapa Arroz e Feijão, whose headquarters is in Santo Antônio de Goiás, GO, Brazil. Assays were carried out in the agricultural microbiology laboratory at IF Goiano - Campus Rio Verde and the antifungal activity of essential oil from $M$. paniculata leaves was evaluated in agreement with the disc-diffusion method described by Xavier et al. (2016), at 12.5-300 $\mu \mathrm{L}$ doses of essential oil (Figure 2). Negative controls were dishes with no addition of essential oil (witness) whereas the positive control was the fungicide Frowncide $500 \mathrm{SC}$, at $10 \mu \mathrm{g} / \mathrm{mL}$ of active ingredient. Petri dishes were sterilized and prepared with PDA culture medium. After medium solidification, essential oils, at the previously mentioned doses, were added and smeared on the surface of the dish with the help of a Drigalski spatula. Afterwards, $5 \mathrm{~mm}$ diameter PDA medium discs with 10-day-old mycelia were placed in the center of the dishes. Then, they were incubated at $28 \pm 2{ }^{\circ} \mathrm{C}$. Mycelial growth was measured daily, until the fungus had fully grown on the control dishes. The treatment was carried out in quadruplicate and the experimental design was thoroughly randomized. Data were submitted to the analysis of variance (ANOVA) and the means of the treatments were evaluated by the Scott-Knott test at $5 \%$ significance level by the ASSISTAT software.

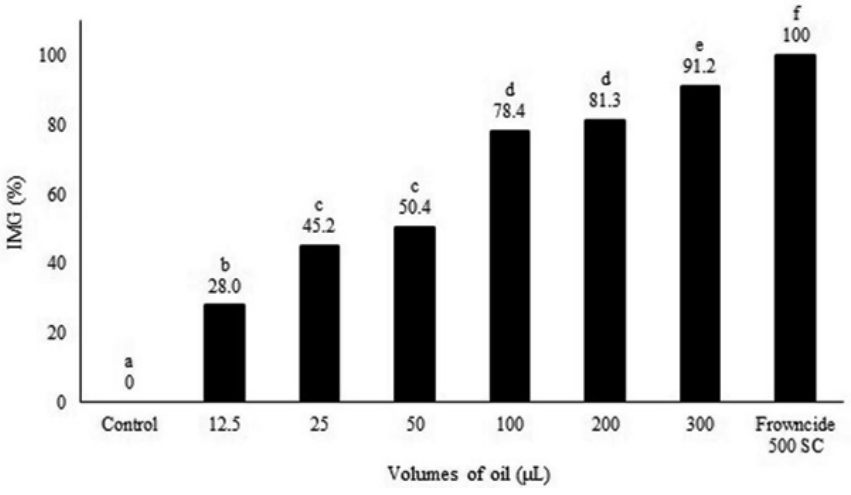

Figure 2. Percentages of inhibition of mycelial growth of Sclerotinia sclerotiorum at different doses of essential oil from $M$. paniculata (ML-EO) leaves. Means followed by the same letter do not differ from each other by the Scott-Knott test.

The percentage of inhibition of mycelial growth (IMG) was calculated by the following formula 1 :

$\operatorname{IMG}(\%)=\frac{(\text { control growth }- \text { treatment growth })}{\text { control growth }} \times 100$

\section{Results and discussion}

Extraction of essential oil from Murraya paniculata (ML-EO) leaves yielded $0.6 \%$. Both GC-MS and GC-FID identified 16 chemical constituents in it, corresponding to $97.7 \%$. Retention times, identified compounds, retention indexes and relative percentages (\%) are shown in Table 1. Major components found in ML-EO leaves were $\beta$-caryophyllene (1) (23.8\%), $\alpha$-zingiberene (2) (21.0\%) and $\beta$-cubebene (3) (10.2\%) (Figure 3).

Previous reports on essential oil from leaves of other M. paniculata specimens have indicated that terpenes predominate in it and that its chemical composition varies significantly, depending on the origin of the plant. For example, essential oil from leaves of plants cultivated in Bangladesh had the following seven major constituents: caryophyllene oxide, $\beta$-caryophyllene, spathulenol, $\beta$-elemene, germacrene $\mathrm{D}$, cyclooctene and 4-methylene-6-(1-propenylidene) (Chowdhury et al., 2008), whereas essential oil collected in Nepal provided methyl palmitate, isospathulenol, $(E, E)$-geranyl linalool, benzyl benzoate, selin-6-en-4-ol, $\beta$-caryophyllene, germacrene $B$, germacrene $D$ and $\gamma$-elemene as its major constituents (Dosoky et al., 2016). In essential oil from leaves from mountains in Central Cuba, $\beta$-caryophyllene was found to be the only major constituent (Rodríguez et al., 2012). However, in Nigeria, essential oil from leaves had seven major constituents, i. e., $\beta$-cyclocitral, methyl salicylate, trans-nerolidol, $\alpha$-cubebene, (-)-cubenol, $\beta$-cubebene and isogermacrene (Olawore et al., 2005).

In Brazil, both terpenes $\beta$-caryophyllene and $\alpha$-zingiberene were the major constituents of essential oil from $M$. paniculata leaves collected in Espírito Santo state (Selestino et al., 2017). The chemical composition of essential oil from M. paniculata leaves collected in Goiás state was similar to the one reported 


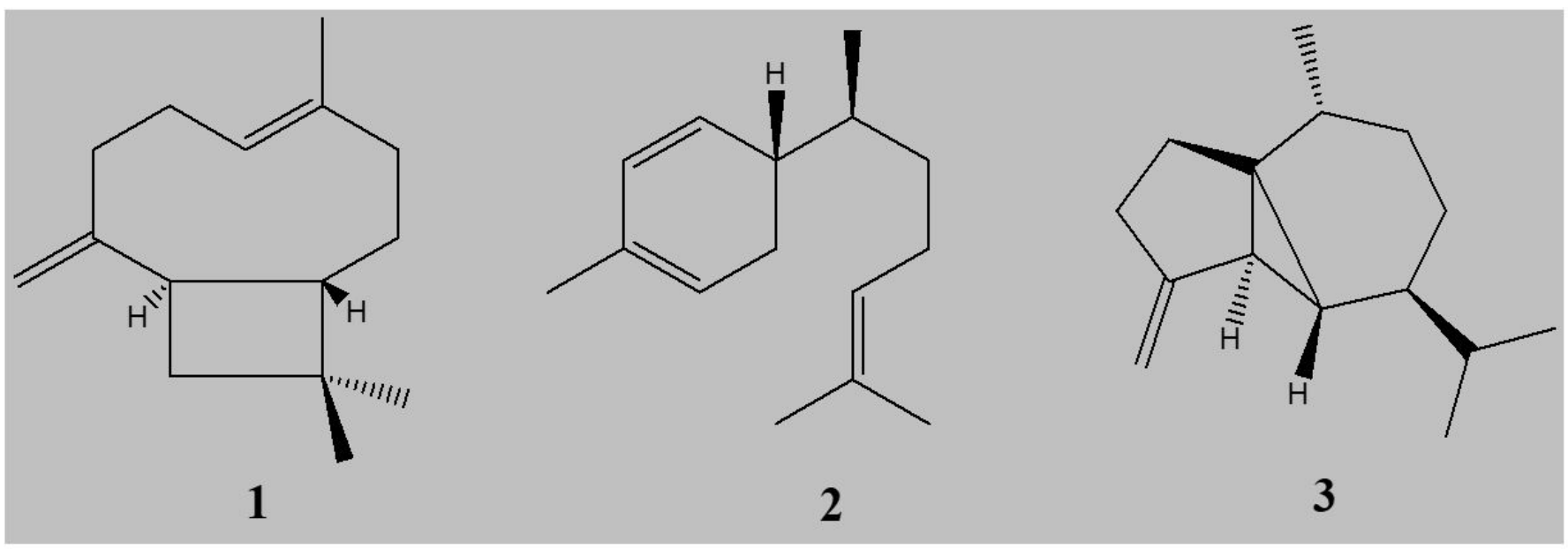

Figure 3. Chemical structures of major constituents identified in the essential oil from M. paniculata leaves: $\beta$-caryophyllene (1), $\alpha$-zingiberene (2) and $\beta$-cubebene (3).

by Selestino et al. (2017), but it differs regarding $\beta$-cubebene (10.2\%), which was identified as the third major component of ML-EO while it had not been found in the oil extracted in Espírito Santo.

Antifungal potential of essential oils against phytopathogens has increasingly drawn researchers' attention worldwide (Silva et al., 2018; Romagnoli et al., 2010), since these oils may act as biofungicides and replace chemical fungicides. Therefore, in vitro antifungal activity of essential oil from $M$. paniculata leaves was evaluated against the phytopathogenic fungus Sclerotinia sclerotiorum. ML-EO inhibited mycelial growth of $S$. sclerotiorum in a dose-dependent manner. Percentages of inhibition of mycelial growth (IMG) of essential oil from M. paniculata leaves are shown in Figure 2.

Results of the analysis of inhibition of mycelial growth showed the promising in vitro antifungal potential of essential oil extracted from $M$. paniculata leaves. The study of the means found by the Scott-Knott test revealed that doses above $12.5 \mu \mathrm{L}$ essential oil from leaves differ statistically from the commercial fungicide Frowncide 500 SC, which was used as positive control (Figure 2). Results also showed that 100, 200 and $300 \mu \mathrm{L}$ doses resulted in $78.4 \%, 81.3 \%$, and $91.2 \%$ inhibition of mycelial growth, respectively. This demonstrated the toxicity of this essential oil at a dose of above $100 \mu \mathrm{L}$ against $S$. sclerotiorum.

The promising in vitro antifungal activity of essential oil from $M$. paniculata leaves may be justified by its major chemical constituents, i. e., $\beta$-caryophyllene (23.8\%), $\alpha$-zingiberene (21.0\%) and $\beta$-cubebene (10.2\%). It is relevant, taking into account that they have already had their antifungal activity reported by the literature (Pereira et al., 2017; Yamamoto-Ribeiro et al., 2013; Xavier et al., 2016). Other determining factors that justify the efficient antifungal activity exhibited by ML-EO are its composition, functional groups found in active components and synergistic interactions (Chouhan et al., 2017).

Essential oils have been known due to their hydrophobic feature, which makes their interaction with lipidic structures easier, increases cellular permeability and causes irreversible damage to cells and, consequently, to microorganisms (Almeida et al., 2012). This mechanism of action also justifies satisfactory results of essential oil from $M$. paniculata leaves against the phytopathogenic fungus $S$. sclerotiorum. In addition, essential oil from $M$. paniculata leaves was more active than essential oil from Cardiopetalum calophyllum and less active than essential oil from Psidium guajava, other species found in the Cerrado in Goiás, since $300 \mu \mathrm{L}$ inhibited $87.6 \%$ and $93.4 \%$, respectively, of mycelial growth of S. sclerotiorum (Xavier et al. 2016; Silva et al., 2018).

\section{Conclusions}

This research showed that essential oil from $M$. paniculata leaves has satisfatory in vitro antifungal activity against S. sclerotiorum, a fungal pathogen that causes damage to many plants of economic interest. Results of this research revealed that there is good prospect of using these essential oils experimentally to control phytopathogens in both greenhouse and field conditions. In terms of chemical composition, major constituents of ML-EO were $\beta$-caryophyllene, $\alpha$-zingiberene and $\beta$-cubebene. In sum, the anti-Sclerotinia sclerotiorum activity of ML-EO may result from synergism among the compounds that constitute the oil.

\section{Acknowledgements}

The authors are grateful to FAPEG, CNPq, CAPES and IF GOIANO for their financial support.

\section{References}

Adams, R. P. (2007). In identification of essential oil components by gas chromatography/quadrupole mass spectroscopy (4th ed., 804 p.). Carol Stream: Allured Publishing Corporation.

Alam, A., Tripathi, A., Sharma, V., \& Sharma, N. (2017). Essential oils: a novel consumer and eco-friendly approach to combat postharvest phytopathogens. Journal of Advances in Biology \& Biotechnology, 11(1), 1-16. http://dx.doi.org/10.9734/JABB/2017/30212.

Almeida, L. F. D., Cavalcanti, Y. W., Castro, R. D., \& Lima, E. O. (2012). Atividade antifúngica de óleos essenciais frente a amostras clínicas de Candida albicans isoladas de pacientes HIV positivos. Revista 
Brasileira de Plantas Medicinais, 14(4), 649-655. http://dx.doi. org/10.1590/S1516-05722012000400012.

Chouhan, S., Sharma, K., \& Guleria, S. (2017). Antimicrobial activity of some essential oils - present status and future perspectives. Medicines, 4(3), E58. http://dx.doi.org/10.3390/medicines4030058. PMid:28930272.

Chowdhury, J. U., Bhuiyan, M. N. I., \& Yusuf, M. (2008). Chemical composition of the leaf essential oils of Murraya koenigii (L.) Spreng and Murraya paniculata (L.) Jack. A. Journal of the Bangladesh Pharmacological Society, 3, 59-63. http://dx.doi.org/10.3329/bjp. v3i2.841.

Dildey, O. D. F., Barbian, J. M., Gonçalves, E. D. V., Broetto, L., Ethur, L. Z., Kuhn, O. J., \& Bonett, L. P. (2014). Inibição do crescimento in vitro de Sclerotinia sclerotiorum, causador de mofo branco, por isolados de Trichoderma spp. Revista Brasileira de Biociências, 12(3), 132-136.

Dosoky, N. S., Satyal, P., Gautam, T. P., \& Setzer, W. N. (2016). Composition and Biological Activities of Murraya paniculata (L.) Jack Essential Oil from Nepal. Medicines, 3(1), 1-10. http://dx.doi.org/10.3390/ medicines3010007. PMid:28930117.

Estevam, E. B. B., Alves, C. C. F., Esperandim, V. R., Cazal, C. M., Souza, A. F., \& Miranda, M. L. D. (2018). Chemical composition, anti-Trypanosoma cruzi and cytotoxic activities of the essential oil from green fruits of Protium ovatum (BURSERACEAE). Revista Brasileira de Fruticultura, 40(1), 1-8. http://dx.doi.org/10.1590/010029452018794.

Estevam, E. B. B., Deus, I. P. B., Silva, V. P., Silva, E. A. J., Alves, C. C. F., Alves, J. M., Cazal, C. M., Magalhães, L. G., Pagotti, M. C., Esperandim, V. R., Souza, A. F., \& Miranda, M. L. D. (2017). In vitro antiparasitic activity and chemical composition of the essential oil from Protium ovatum leaves (Burceraceae). Anais da Academia Brasileira de Ciências, 89(4), 3005-3013. http://dx.doi. org/10.1590/0001-3765201720170310. PMid:29044326.

Fonseca, M. C. M., Lehner, M. S., Gonçalves, M. G., Paula, T. J. Jr., Silva, A. F., Bonfim, F. P. G., \& Prado, A. L. (2015). Potencial de óleos essenciais de plantas medicinais no controle de fitopatógenos. Revista Brasileira de Plantas Medicinais, 17(1), 45-50. http://dx.doi. org/10.1590/1983-084X/12_170.

Mesquita, S. G., Martinez, M. F., Romoff, P., Fávero, O. A., Lieber, S. R., \&Lago, J. H. G. (2008). Constituintes químicos das folhas de Murraya paniculata (Rutaceae). Revista Brasileira de Farmacognosia, 18(4), 563-568. http://dx.doi.org/10.1590/S0102-695X2008000400011.

Olawore, N. O., Ogunwande, I. A., Ekundayo, O., \& Adeleke, K. A. (2005). Chemical composition of the leaf and fruit essential oils of Murraya paniculata (L.) Jack. (Syn. Murraya exotica Linn.). Flavour and Fragrance Journal, 20(1), 54-56. http://dx.doi.org/10.1002/ffj.1365.
Pereira, D. G., Sediyama, T., Reis, M. S., Cruz, C. D., Gomes, J. L. L., \& Teixeira, R. C. (2012). Avaliação da severidade do oídio [Erisyphe difusa (U. Braun \& S. Takam)] em genótipos de soja, em condições de campo. Revista Caatinga, 25(3), 25-30.

Pereira, F. G., Marquete, R., Domingos, L. T., Rocha, M. E. N., FerreiraPereira, A., Mansur, E., \& Moreira, D. L. (2017). Antifungal activities of the essential oil and its fractions rich in sesquiterpenes from leaves of Casearia sylvestris Sw. Anais da Academia Brasileira de Ciências, 89(4), 2817-2824. http://dx.doi.org/10.1590/0001-3765201720170339. PMid:29236852.

Rodríguez, E. J., Ramis-Ramos, G., Heyden, Y. V., Simó-Alfonso, E. F., Lerma-García, M. J., Saucedo-Hernández, Y., Monteagudo, U., Morales, Y., Holgado, B., \& Herrero-Martínez, J. M. (2012). Chemical composition, antioxidante properties and antimicrobial activity of the essential oil of Murraya paniculata leaves from the mountains of central Cuba. Natural Product Communications, 7(11), 1527-1530. PMid:23285823.

Romagnoli, C., Andreotti, E., Maietti, S., Mahendra, R., \& Mares, D. (2010). Antifungal activity of essential oil from fruits of Indian Cuminum cyminum. Pharmaceutical Biology, 48(7), 834-838. http:// dx.doi.org/10.3109/13880200903283715. PMid:20645785.

Selestino, M. C. Na., Vittorazzi, C., Guimarães, A. C., Martins, J. D. L., Fronza, M., Endringer, D. C., \& Scherer, R. (2017). Effects of $\beta$-caryophyllene and Murraya paniculata essential oil in the murine hepatoma cells and in the bacteria and fungi 24-h time-kill curve studies. Pharmaceutical Biology, 55(1), 190-197. http://dx.doi.org/ 10.1080/13880209.2016.1254251. PMid:27927082.

Silva, E. A. J., Silva, V. P., Alves, C. C. F., Alves, J. M., Souchie, E. L., \& Barbosa, L. C. A. (2018). Chemical composition of the essential oil of Psidium guajava leaves and its toxicity against Sclerotinia sclerotiorum. Semina: Ciências Agrárias, 39(2), 865-874. http:// dx.doi.org/10.5433/1679-0359.2018v39n2p865.

Xavier, M. N., Alves, J. M., Carneiro, N. S., Souchie, E. L., Silva, E. A. J., Martins, C. H. G., Ambrosio, M. A. L. V., Egea, M. B., Alves, C. C. F., \& Miranda, M. L. D. (2016). Composição química do óleo essencial de Cardiopetalum calophyllum Schltdl. (Annonaceae) e suas atividades antioxidante, antibacteriana e antifúngica. Revista Virtual de Química, 8(5), 1433-1448. http://dx.doi.org/10.21577/19846835.20160101.

Yamamoto-Ribeiro, M. M. G., Grespan, R., Kohiyama, C. Y., Ferreira, F. D., Mossini, S. A. G., Silva, E. L., Abreu, B. A. Fo., Mikcha, J. M. G., \& Machinski, M. Jr. (2013). Effect of Zingiber officinale essential oil on Fusarium verticillioides and fumonisin production. Food Chemistry, 141(3), 3147-3152. http://dx.doi.org/10.1016/j. foodchem.2013.05.144. PMid:23871071. 